\title{
Ssciendo
}

Ethics \& Bioethics (in Central Europe), 2018, 8 (1-2), 91-108

DOI:10.2478/ebce-2018-0011

\section{Specifics of introducing a code of ethics into the academic environment}

\author{
Martin Lačný, ${ }^{1}$ Jana Lukáčová ${ }^{2} \&$ Iveta Kovalč́́ková $^{3}$
}

\begin{abstract}
The implementation of tools and techniques of the management of ethics in the academic environment has its own peculiarities arising from the nature of the expert, scientific, pedagogical, but also administrative work of university staff, requiring a considerable degree of autonomy and freedom. The aim of this case study is to present the views of university teachers and $\mathrm{PhD}$ students from a selected faculty of a public university in Slovakia on the implementation of tools and techniques for the management of ethics and to identify specific risks associated with the nature of the code of ethics and its introduction into practice. Qualitative research was conducted using focus groups during the implementation of the code of ethics, while quantitative research was subsequently conducted by an anonymous electronic questionnaire shortly after the introduction of the code into practice.
\end{abstract}

Keywords: social norms, ethical infrastructure, code of ethics, academic environment, focus groups

\section{Introduction and theoretical background}

Institutionalized moral values are understood to be an effective tool for the strategic development of an organization; a tool for building trust and collective identity, the reputation of a fair player, and an important tool for building the institutional brand. In the current atmosphere, it seems that successful organizations of tomorrow will no longer be mere institutions without their own faces, they will have to be presented as if they were individual entities - as intelligent entities with a non-distorted character who deal with their own employees and their surroundings in a fair way. Positive initiatives that help cultivate and ethically mobilize our practice include solutions related to the building of responsible mechanisms and models of social responsibility. In this context, it could be said that at present, organizations of various kinds are usually involved in the removal of undesirable phenomena that are harmful to the fulfilment of their collective goals, while in connection with their ethical infrastructure, create tools that serve employees and managers to reveal harmful and unethical practices (Remišová, 2004, pp. 150-153). In creating an ethical infrastructure, the organization is primarily concerned with the application of codes of ethics, training and education of employees and managers in the field of occupational ethics, ethical and social audit, etc. Y1ldız, Içli and Gegez (2013) draw attention to the fact that for almost all occupations there is a striking attempt to create a code of ethics within the reference framework of one's own profession. The existence of an code of ethics within a profession means that unethical behaviour is not allowed and cannot be tolerated. The ethical infrastructure introduced, as it becomes part of the culture of the organization, necessarily reflects the impact of traditions, rituals, and key principles of organizing values that are accepted within the organization (Lašáková, 2005).

\footnotetext{
${ }^{1}$ University of Prešov (Slovakia);email: martin.lacny@unipo.sk

${ }^{2}$ University of Prešov (Slovakia);email: jana.lukacova@unipo.sk

${ }^{3}$ University of Prešov (Slovakia);email:: iveta.kovalcikova@unipo.sk
} 
The concrete form of the institutionalization of ethics in an organization depends on the qualitative and quantitative factors that affect it. Qualitative factors include the level of ethical thinking of the management, the type of organization in terms of its activities, the value orientation of employees, the educational structure of the staff, the specific moral situation in the organization, the economic situation of the organization, its perspective, as well as the quality of the preparation of the content, form, and course of the ethical program itself. The category of quantitative factors influencing the institutionalization of ethics include, for example, the size of the organization, the length of its existence, the age structure of the staff, and so on. (Remišová, 2004, p. 107). The fundamental objective of implementating tools and techniques for the management of ethics is to help shape the ethical orientation of the staff, to strengthen behavioural patterns that are consistent with group ethical principles and vice versa, to suppress behaviour that is inconsistent with the shared values. A good and functional ethical infrastructure can simplify and accelerate the resolution of situations where the organization has conflicts of interest and compromise is needed.

There are traditional and modern tools and techniques for the management of ethics sectioned in literature. As mentioned by Remišová, Putnová and Seknička, traditional instruments include codes of ethics, ethical credo and leitmotifs, as well as training and education in the field of relevant professional ethics (Remišová, 2004, pp. 107-108; Putnová \& Seknička, 2007, pp. 70-71). Among the modern tools that emerged in practice at the turn of the 1980s and 1990s and are currently used mainly in the corporate sphere, include ethical and social auditing, the position of the ombudsman, ethics committees and commissions, ethical discussion forums and ethical hotlines.

Human resources management is an area where most ethical problems arise. Indeed, people are one of the key components of organizations, and from the occupational management point of view, it is probably the most difficult task to reconcile their individual preferences, interests, value systems with the collective goals and values. Modern management theories, characterized by their praxeological character, emphasize the commitment of employees to the activities of the organization in question, which presupposes their voluntary identification with the organization, its intentions, and objectives (Slywotzky, 1996; Griseri, 1998; Russell-Jones, 2006; Armstrong, 2007; Miller, 2008; Cipro, 2009; Cejthamr \& Dědina, 2010; Blažek, 2011; Chovancová \& Huttmanová, 2014). In this respect, the key element determining the character and quality of human relationships at the workplace and employers' relationships is therefore trust. Creating an atmosphere of trust, especially from the point of view of motivating employees and managers, means paying attention to the transparency and striving for fair solutions to specific (not only) conflict-inducing situations.

In this context, together with the above-mentioned tools and techniques of the management of ethics in the ethical infrastructure of the organization, it is essential for the organization to introduce into practice basic methods of dialogue when it comes to the question of ethics, and consensus in the area of group values. The basis for the implementation of ethical principles, tools, and methods is the analysis of the organization's situation that identifies the most common ethical conflicts and identifies managerial and staff views (formal and informal authorities) on ethical management. ${ }^{4}$ Based on the results of the ethical audit, the goals that

\footnotetext{
${ }^{4}$ In this context, we can speak of a consensus authority or a consensual legitimate authority, which can also be understood as an acceptable justification for the structure, functions, and objectives of a certain ethical infrastructure of the organization from general ethical and cultural-political perspectives. This type of authority is to be understood not in terms of rational technical knowledge but knowledge and abilities that lead to the
} 
should be achieved through the ethical program in the organization are personal ethical commitment and the employees' commitment to organizational values. Since the institutionalization of ethics in the organization is a matter of strategic management, it is necessary to emphasize the communication aspect of the process in its implementation. As it is in the case of corporate strategy, even the best-thought-out and prepared ethical infrastructure will not work if it is not understood and accepted by all the stakeholders involved in the organization's activities.

A functional ethics program also includes various forms of control of its effectiveness (Kaptein, 2009). In practice, organizational culture (and, in its context, ethical infrastructure) is essentially a living organism, which is manifested by its dynamic nature; its individual parts can vary depending on the results achieved in the development of the ethical climate in the organization. Within the organizational culture, institutionalized values regulate the functioning of the group by serving as a guide to behaviour in a dual way - some correlate with the basic beliefs and current behaviours, while others rather express aspirations for the future (not necessarily coinciding with current behaviour). In both cases, they provide the members of the organization with a framework of expectations, motivation, or attitudes. In key situations in the life-cycle of the organization, they help reduce uncertainty and maintain the continuity of the organization's functioning by providing a comprehensive, summative, and, consequently, wider view of reality (Lašáková, 2006, p. 246). Since the ethical norms of the social groups in which a person moves or to whom they are directed, play a very important role in the life of each individual, it is of utmost importance to establish an ethical standard that requires professional and occupational inclusion. The most important and most widely used instruments of ethical institutionalization are, in this respect, codes of ethics in which the institution, enterprise, or other group of people gives their members and their surroundings the awareness of the fact that ethics has become an essential part of its activities. The code of ethics extends the range of the tools of human resources management (Remišová, 2011, p. 22). The main function of codes of ethics is to regulate individual or group behaviour in accordance with the collective ethical standards. This regulation should be based on existing legal standards and complement them in a specific way. The code of ethics should complement the law, especially in areas where legal regulation is no longer needed but can not be left without any regulation. In such areas, codes of ethics become the basic elements of self-regulation. As Remišová, Putnová and Seknička mention, their further key functions include support for organizational culture and the socialization process, as they are an important tool for leading people in an organization, becoming an important framework of assessment of their own activities by employees and the public, while at the same time fulfilling the function of a doctrine (they are the authorizing documents) (Remišová, 1998, pp. 11-13; Putnová \& Seknička, 2007, pp. 75-76). In practice, those codes whose functionality is built on their aspirational, educational, and regulatory aspects are extensively used. As Remišová and Winkler have observed, Slovak companies prefer the type of code which specifically lists problem areas and is less general. These codes of ethics contain both ethical spheres reflecting the real moral problems of the company as well as ethical spheres that have a prophylactic value for the company (Remišová \& Winkler, 2006, pp. 169-173). Although the form and language of the codes can be flexibly adapted to the specific situation and

general goals of the organization. The term "consensual authority" is understood in the sense of a passive consensus, not in terms of the active consensus of entities involved in the activities of the organization. 
character of the organization, industry or profession, every code of ethics must be clear and unambiguous (Messikomer, 2010). In no case should it create room for different interpretation or doubts as to the interpretation of its individual provisions.

When implementing codes of ethics and other components of ethical infrastructure, it is necessary to take into account the diversity of legal and organizational forms and the associated differences in the application of the principle of accountability in organizations. At the same time, it is necessary to emphasize that, when distributing responsibility within an organization, we must distinguish between situations where responsibility can be attributed to specific individual subjects and those where we can talk about the social responsibility of an organization as a collective moral entity (Lačný, 2012, pp. 63-64).

Defining ethical standards in an academic environment is a complex process. The code of ethics in an academic environment differs from moral standards that can be applied within a specific culture, education, religion, or society as a whole. University educators work in positions of mentors/educators, researchers, administrators, consultants, and professional team partners. The American Association of University Professors (AAUP), defines in its code of ethics the frameworks for the ethical behaviour of academics as educators (see www.aaup.org). The code of ethics is perceived as an effective tool as well as an adviser, especially for novice teachers (Dean, 1992). Several professional associations of educators, including The Academy of Management (AOM) and The American Marketing Association (AMA), have developed codes of ethics for the purposes of increasing the level of responsible and professional behaviour in a defined professional environment (Dean, 1992; Gao et al., 2008).

When codes of ethics are developed and implemented in the right way, they play an important regulatory role (Higgs-Kleyn \& Kapelianis, 1999; Kaptein, 2004; Garegnani, Merlotti \& Russo, 2015). In the academic environment, codes of ethics also perform the following functions: define the behaviour that is possible and acceptable, define behaviour that is considered unethical, are the source of system support, assessment, reviewing and decision making at the university.

In order to gain a realistic picture of the perception of ethical parameters in the university sector, several surveys have been carried out, particularly in developing democracies. For example, in a survey at the South East European University (SEEU) in Macedonia, the views of ethical and moral values on the professional life of the interviewed respondents were examined in a number of university teachers and students (Murtezan, Merxhivan \& Mentor, 2010). The research results were used to create a code of ethics that was perceived in the environment of the mentioned university as a supportive tool for creating frameworks for professional behaviour. Yıldız, Içli and Gegez (2013) draw attention to the absence of codes of ethics in the academic environment of Turkish universities and focus on identifying the code of ethics of tertiary educators, which is mainly tied to their role as teachers/educators.

The implementation of tools and techniques of the management of ethics in the academic environment has its specificities, arising from the nature of the professional, scientific, pedagogical and administrative work of university staff, requiring a considerable degree of autonomy and freedom. Bruhn, Zajac, Al-Kazemi and Prescott consider the nature of so called "good citizenship" in connection with professionalism and their application in the academic sphere (Bruhn, Zajac, Al-Kazemi \& Prescott, 2002, pp. 461-493). On the basis of practical experience with the implementation of codes of ethics Remišová's and Lašáková's findings have important theoretical, methodological, and practical implications in relation to 
the implementation of codes of ethics at public higher education institutions, respectively in the academic environment in general. Their practical recommendations include a verified sequence of steps, or rather stages of the implementing of codes of ethics in the academic environment, consisting of setting the objective (or objectives) for implementation, analysis of the organization's ethical environment (faculties, universities), subsequent specification of access to the preparation and implementation of the code, and the definition of the control mechanisms in relation to upholding the code of ethics (Remišová \& Lašáková, 2012, pp. 61-74). Jankalová, Jankala, Blašková and Blaško analyse the reasons for the need to create and implement a code of ethics within a case study at the University of Žilina, Slovakia (Jankalová, Jankala, Blašková \& Blaško, 2014). An analytical view of the character and the implementation of codes of ethics in the environment of Slovak universities is applied by Králiková and subsequently by Platková Olejárová in the context of analysising the state of professional ethics in Slovakia, presented in a edited volume, which deals with current issues of professional ethics in Slovak education (Králiková, 2009; Platková Olejárová, 2012a, pp. 151-168; 2012b, pp. 215-265; Gluchman et al., 2012, pp. 215-284).

The aim of our study was to search for opinions and attitudes related to the implementation of codes of ethics and to identify specific risks related to the nature of codes of ethics and their introduction into practice in the academic environment. Our sample of respondents consists of university teachers ${ }^{5}$ and full-time PhD students working at a selected faculty of a public higher education institution in Slovakia.

\section{Method}

To explore the effects of implementing tools and techniques for the management of ethics, we have chosen a mixed design of research based on a qualitative and quantitative approach. The qualitative approach provides an initial exploration of the issue and a deeper insight into the subject matter, examining individual phenomena in the natural environment, looking for causation and creating a theory (Hendl, 2005). Since qualitative research does not allow the generalization of results, we have supplemented the method by using quantitative questionnaire research, which collects data on a representative sample of respondents with pre-prepared questions and defined categories (Silverman, 2005).

Qualitative data was obtained through using focus groups. This method reveals the views of individuals in a small group that is deliberately designed to represent the various categories of individuals involved in the subject of research. Participants during a group interview respond to the questions asked, while listening to the opinions and attitudes of others. So they can change their own ideas and discuss the topic in broader contexts, which brings more complex information to the researcher. As part of a group interview, the speakers clarify and justify their views. The role of moderators in the debate is to facilitate group processes through democratic leadership in order to ensure a free exchange of views while maintaining respect, friendly atmosphere, and trust (Plichtová, 2002).

On the subject of the implementation of codes of ethics, two focus groups were set up at a selected faculty of a public university in Slovakia. ${ }^{6}$ Data collection took place in May and June, 2012. Eight teachers and internal PhD students were assigned to each group in order to ensure the heterogeneity of the sample according to the scientific-pedagogical title, or rather

\footnotetext{
${ }^{5}$ For the sake of simplicity, we will only use the term 'teachers' in the following text.

${ }^{6}$ To maintain anonymity in the study, we do not provide data that could identify a particular university, faculty, or respondent.
} 
by job classification: two professors, two associate professors, two assistant professors, and two internal $\mathrm{PhD}$ students. The number of teachers who accepted the invitation is listed in table no. 1.

The studied sample was made up of respondents who represented 8 out of 13 organizational units of the faculty. Discussion on one topic lasted 45 to 60 minutes. $^{7}$

Table no. 1: The representation of teachers and internal PhD students based on gender in the focus groups

\begin{tabular}{llcccc}
\hline T. group & Women & $\begin{array}{c}\text { Internal } \\
\text { PhD } \\
\text { Students }\end{array}$ & $\begin{array}{c}\text { Assistant } \\
\text { professors }\end{array}$ & $\begin{array}{c}\text { Associate } \\
\text { professors }\end{array}$ & Professors \\
& Men & 2 & 1 & 0 & 1 \\
2. group & Women & 0 & 1 & 2 & 0 \\
& Men & 2 & 1 & 2 & 0 \\
Total & & 1 & 4 & 0 & 1 \\
\hline
\end{tabular}

The groups were led by a pair of moderators in a non-discriminatory manner. The moderators supported every participant's response to each question asked. The anonymity of the speakers was ensured by not disclosing personal data such as gender, age, or job classification when it comes to the individual statements cited in the study, as it involved a relatively narrow selection of teachers and internal $\mathrm{PhD}$ students from one faculty. The participants' responses were recorded with their consent on an audio recorder for the purposes of detailed data processing.

Participants in the discussions in both focus groups were asked the following questions about the institutionalization of ethics:

1. With which instruments for the implementation of ethics in organizations (codes of ethics, ethical leitmotif, position of an ethics manager, ombudsman, ethics committee, ethical round tables, ethics seminars, ethical workshops, ethical discussion forums, ethical hotline, ethical balance sheet, ethical audit) do you have direct practical or at least mediated experience? Which of these tools do you consider to be the best way to implement ethics in the academic sphere?

2. What aspects do you think should be taken into account when communicating deployed tools to implement ethics in an organization (at university, at a faculty)? What do you expect from a functional ethical infrastructure, consisting of the appropriate combination of these tools? (What specific effects should its implementation bring?) What undesirable effects should the organization (university, faculty) avoid when implementing these tools?

The data from the audio recorder was thoroughly recorded, the transcription was controlled by repeated listening. A descriptive approach was used to create categories with open encoding, and the results were checked by other researchers for greater objectification in

\footnotetext{
${ }^{7}$ The topic of the implementation of the code of ethics has been explored in the context of broader research into academic ethics. Other partial topics of research included issues of teacher identity, interpersonal relations in the academic environment (teacher-teacher, teacher-student relationships), ethics of scientific work, and academic freedom issues. In one focus group, two of the issues studied were discussed for a total duration of 90 to 120 minutes.
} 
transcription coding. The individual results are amended with direct quotes in the text of the study to increase the validity of encoding.

In the framework of quantitative research, which was subsequently implemented on the basis of the background knowledge, facilitated by the analysis of the recorded discussions in the focus groups, the topic of institutionalizing ethical standards in an anonymous electronic questionnaire was represented by two questions. ${ }^{8}$ The formulation of questions resulted from the summary of the given focus groups discussions. Data collection took place in January and February, 2013. The anonymity of the respondents was guaranteed by the use of the Google docs web application, through which the questionnaire was created and managed. A link to an electronic questionnaire was distributed to teachers and internal $\mathrm{PhD}$ students operating on the selected faculty via bulk email, individually for teachers and internal $\mathrm{PhD}$ students as well. 64 respondents were involved in the research, including 41 teachers (representing $22 \%$ of teachers from the chosen faculty) and 23 full-time $\mathrm{PhD}$ students (representing $28 \%$ of internal $\mathrm{PhD}$ students). The average age of the teachers was 44.51 years $(\mathrm{SD}=13.04, \min =24, \max =$ 68 years) and internal doctoral students 27.09 years $(\mathrm{SD}=1.62, \min .=24, \max .30$ years $)$. The sample number by gender and job classification is shown in table no. 2 .

Table no. 2: Representation of teachers and internal PhD students involved in questionnaire research based on gender $(N=64)$

\begin{tabular}{lcccc}
\hline & $\begin{array}{c}\text { Internal } \\
\text { PhD } \\
\text { students }\end{array}$ & $\begin{array}{c}\text { Assistant } \\
\text { professors }\end{array}$ & $\begin{array}{c}\text { Associate } \\
\text { professors }\end{array}$ & Professors \\
\hline Women & 15 & 13 & 1 & 7 \\
Men & 8 & 15 & 2 & 3 \\
Total & 23 & 28 & 3 & 10 \\
\hline
\end{tabular}

The results were processed using descriptive statistics in SPSS 15.0. Due to the insufficient fulfilment of the different categories of teachers according to job classification, it was decided to proceed to a summary evaluation of the results for the whole set of teachers, including internal $\mathrm{PhD}$ students.

\section{Research Results}

The implementation of tools and techniques for the management of ethics in the organization has been strongly associated with the introduction of a code of ethics in the opinions presented by both focus groups. The statements of the speakers in these focus groups were primarily focused on four areas, including:

1. The nature of the code of ethics,

2. The nature and process of its implementation,

3. The undesirable effects that need to be avoided within the implementation,

4. The commitment of the faculty management to the code of ethics as a tool of the management of ethics.

\footnotetext{
${ }^{8}$ The questionnaire included a total of 22 questions related to academic ethics that are relatively independent and can be evaluated individually according to the individual sub-topics of research.
} 


\section{The nature of the code of ethics}

In the context of current events at the chosen faculty, which were influenced by the efforts to introduce a code of ethics in the given period, the participants expressed their opinions particularly in terms of its nature: ${ }^{9}$

- According to the participants, the code of ethics should be "a brief and clear declaration of the university's values, or the faculties which are agreed upon by the academic community".

- It should not be of a restrictive nature, it should be more of a "map" - a tool that helps in one's orientation.

- "The goal of its implementation should be the academic community's cohesiveness within the faculty and true equality in the broadest sense [...]". Its main contribution, apart from the mentioned cohesiveness, should be its motivating vision (its motivational part) that must be clearly specified (at present, according to some speakers, it is not entirely clear in what aspect should the employees of the university be better or rather the best).

- Part of the views of the speakers point to the importance of the regulatory function of the code of ethics, which "aims to moralize and eliminate unacceptable behaviour and to create the boundaries of desirable behaviour, or more specifically the rules of the game for all levels of relationships" - including relationships between teachers and students, ensuring that self-esteem and respect for others are not impaired. However, it should (in terms of the manner in which it is conducted) "distinguish between the regulatory aspect of the code of ethics, and the regulation of behaviour through the internal regulations of the faculty, i.e. valid legislative norms".

- In formulating the code of ethics, "it is necessary to reflect on the effectiveness of individual instruments in order to bring about what is in line with the primary purpose of their use [...]". The discussion also suggested that "according to current experiences with the introduction of the code of ethics at the selected faculty, this effectiveness is still absent". ${ }^{10}$

\section{The nature and process of the implementation of code of ethics}

Within the process of implementation of the code of ethics itself, it is necessary, according to the debaters in the respective focus groups, not to forget to mention a few important moments:

- The code should be "alive" and functional (not a code for the sake of a code), "the tools should not become purpose."

- The code of ethics should be accepted by the academic community, "it cannot come from 'above.' It should be based on a continuous ethical audit and must not be formalized, unchangeable, [...]," its continuous transformation should be brought on by the ongoing evaluation of the situation at the faculty.

- Even before implementing the code, "structural changes necessary to change behaviour have to be done to avoid repeating old mistakes". According to some participants, the main problem with the selected faculty is not that some people do not know how to behave, but that they do not behave as they should. In this context, the

\footnotetext{
${ }^{9}$ With regard to maintaining the anonymity of the participants, we do not give any further details of their job classification, gender or age.

${ }^{10}$ Discussions in the focus groups took place about a half a year before the final version of the code of ethics was submitted to the Academic Senate of the Faculty for evaluation.
} 
view was expressed that "the absence of a code of ethics is not the cause of unethical behaviour". More important than the code is "creating a moral climate in a workplace that would be a natural regulator of behaviour".

- The process of implementing the code of ethics should be based on "openness of the institution in communication" (not to send a drafted code of ethics via email and set a one-week deadline for possible comments), "the code should be presented as a consensus vision".

- "The professional skills of the experts we have at university should be used in the implementation processes" (e.g. sociologists' professional abilities in creating a questionnaire, etc.). Otherwise, in any given environment, the implementation process of any tool becomes opaque.

- The discussion also expressed the view that the functionality of the code of ethics could be supported by the work of the ethics committee.

\section{The undesirable effects that need to be avoided within the implementation}

Another substantial part of the opinions of the focus groups participants consisted in defining the undesirable effects that need to be avoided in implementing the code of ethics:

- "We should avoid negative effect in the form of limiting academic freedom [...]." In this context, negative associations were expressed with the intention of putting everyone into a single framework, generalizing, unifying the rules of conduct and behaviour, using the code of ethics as a tool of power. The freedom of conduct synonymous with the concept of Universities is thus threatened. The code of ethics, according to the views of the speakers, should not be an instrument of power.

- It has been suggested that "the university should have the ability of self-regulation, which should be supported by the code of ethics, not to be negated by its synthetic character".

- "It is necessary to prevent reasons leading to moral schizophrenia (to behave like: disguise and you have no problem - if you are honest, you have a problem [...]) due to non-compliance with the requirements for employees and codified ethical standards [...]" (e.g. quantitative criteria vs. the quality of published texts, plagiarism, etc.). Several speakers in this context have pointed out that it is counterproductive when one's practical compliance with the codified standards is not rewarded in any way when one is motivated towards unethical behaviour by delivering effects (in particular related to one's performance) that are expected from him/her.

- "The code of ethics or any other management instrument may not work on an acrossthe-spectrum basis". It is a mistake that even though it would eliminate the laziness of a certain percentage of people; however, most faculty members would be affected by the measure, significantly reducing the space for competent individuals to deliver high working performance.

- "It is necessary to avoid tendencies leading to a schematic action, such as: fearing to give one's own opinion, to step out of the crowd, to get involved, to be different while living with the stress that we are doing something other than the code of ethics requires."

- Some speakers have expressed concern whether a code of ethics - even the most sophisticated - can solve all problematic situations (for example, when fellow teachers 
are gossiping, questioning each other, or putting each other down in front of students at lectures), fears to what extent can the code actually influence the inner morale of people.

- "It is necessary to avoid overly general formulations in the code that can not capture all the problems". Several commentators expressed concern about the emergence of so-called "deaf holes" that will be used in practice and the provisions of the code will thus lose their effect. At the same time, however, some have pointed out that we can not define all the behavioural variants that may occur, so it may happen that sometimes a specific action can be considered as a violation of the code's provisions, and sometimes it does not have to be so.

- It has also been suggested that the code of ethics generally disturbs the intimate morale or the inner convictions of individuals. However, it was a unique attitude that did not find a positive response within the discussion group in which it was presented.

- Several times, a negative association with the moral code of building Communism has been presented in the discussions, in connection to which personal experience evokes scepticism and doubt over any binding rules, however well-meaning they are. The speakers who opposed this opinion understand the need to define values, but also present a defensive response to the codification of rules that could limit the academic freedom typical for the university environment.

4. The commitment of the faculty management to the code of ethics as a tool of the management of ethics

Some of the respondents' reactions were related to the issue of the faculty management and its commitment to the code of ethics:

- In this respect, the view that "the code of ethics is justified under the condition that management (on the level of the Deanery, Rectorate) would present the code as an initiative to which it will itself commit" may be considered representative. Whoever creates the code should be a moral leader in order to motivate. Repressive "top-down" measures do not motivate.

- In a similar spirit, there were statements that, in the first place, the code of ethics should be upheld by the members of the management that implements the code. "The relationship of the faculty's management and staff with the code cannot be asymmetrical".

- "In terms of staff motivation, the management should be a moral model in terms of compliance with the code". In this respect, the management requirements and requirements of the code of ethics should be in alignment - the performance rating system must not be set in such a way as to force employees to violate ethical standards and hence the code of conduct by reducing the quality of publications and autoplagiarizing in order to meet quantitative criteria.

- According to the both focus groups participants, "the code of ethics should be an instrument that obliges management to create the conditions for the performance of creative employees, because performance does not just rely on them, but the conditions under which they have to meet their requirements". 
In an effort to reflect problematic areas, which most of the speakers pointed out, two questions were formulated into the questionnaire used in the quantitative part of the research. In it, the weight of the individual problematic moments related to the creation and implementation of the code of ethics, which were defined by the participants in the focus groups, and the manner in which the faculty teachers evaluate the code of ethics as a tool of the management of ethics in terms of expected effects has been verified. The formulation of both questions resulted from the problematic moments indicated by the participants of our focus groups. The questionnaire was distributed to respondents several weeks after the faculty management introduced the new code of ethics.

The first of the two questions included in the research tools on the implementation of the code of ethics was formulated as follows:

- When introducing a code of ethics, it is important (you can mark several options):

a) To align its wording with the legislation and internal rules of the institution.

b) The code should result from the consensus of the "representatives" of the academic community.

c) The code should be the result of the consensus of the entire academic community, not only its representatives.

d) The creation of the code should make use of the expertise of the faculty.

e) It is necessary to ensure compliance with the code by all persons involved (students, teachers, faculty management).

f) Other...

a) To align its wording with the legislation and internal rules of the institution

b) The code should result from the consensus of the "representatives" of the academic community

c) The code should be the result of the consensus of the entire academic community, not only its representatives

d) The creation of the code should make use of the expertise of the faculty

e) It is necessary to ensure compliance with the code by all persons involved (students, teachers, faculty management)

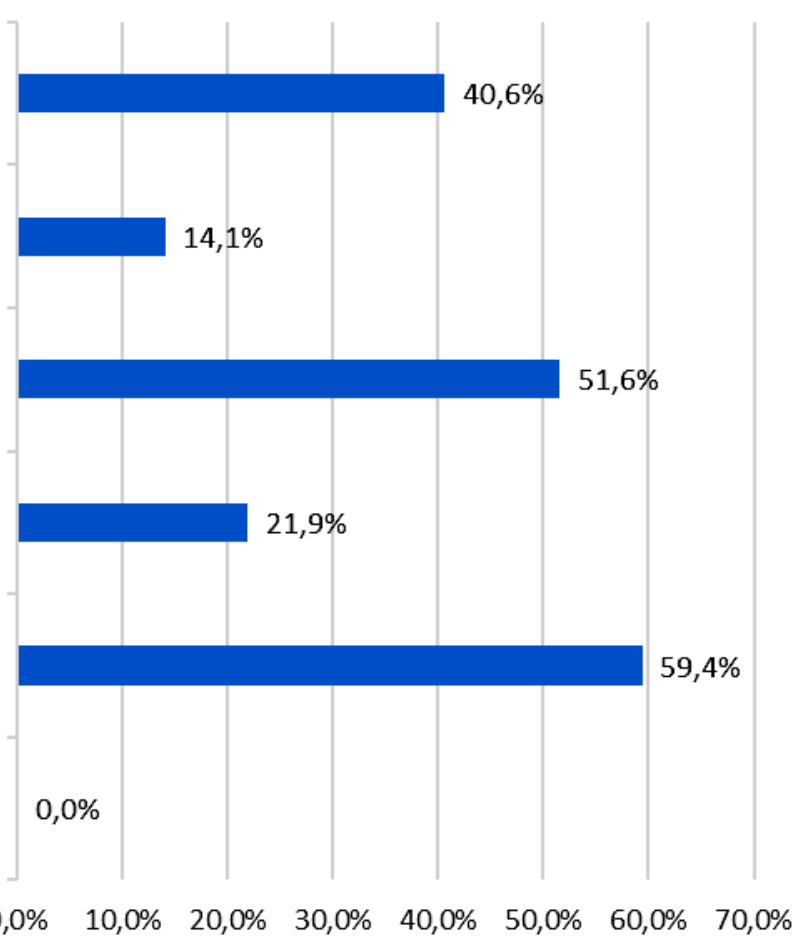

Chart no. 1: The answers of the respondents to the question: "When introducing a code of ethics, it is important..." $(\mathrm{N}=64)$ 
In accordance with the given sample of participants, it was found out that the most important moment in the implementation of the code of ethics is ensuring their compliance by all stakeholders, i.e. students, teachers and faculty leadership (59.4\%, or 38 respondents). The second moment in order of their importance is, according to the respondents, to ensure that the code of ethics is the result of the consensus of the entire academic community, not only its representatives $(51.6 \%$, or 33 respondents). On the other hand, the possibility that the code should be the result of a consensus of representatives of the academic community was identified by $14.1 \%$, or 9 respondents. The third most important aspect of the implementation of the code of ethics should be to ensure its compliance with the legislation and internal rules of the institution $(40.6 \%$, or 26 respondents). Acknowledging that the expert skills of the faculty should be used in the drafting of the code of ethics, $21.9 \%$ agreed, or 14 respondents. An overview of the percentage distribution of responses to the issue in question is given in chart no. 1. Respondents did not use the open answer "Other", so it is not shown in the chart.

The second of these questions, aimed at evaluating the code of ethics as a tool for the management of ethics in terms of the effects expected by teachers and internal $\mathrm{PhD}$ students at the faculty, was formulated as follows:

- How do you assess the code of ethics as a tool for the management of ethics at the faculty?

a) It is an instrument that will positively influence the organizational culture.

b) It is an instrument that can positively contribute to the organization.

c) This tool will have a neutral, or negligible effect on the organizational culture.

d) I expect more or less negative effects from the code of ethics.

e) The code of ethics will have significant negative effects on the faculty.

f) I cannot say.

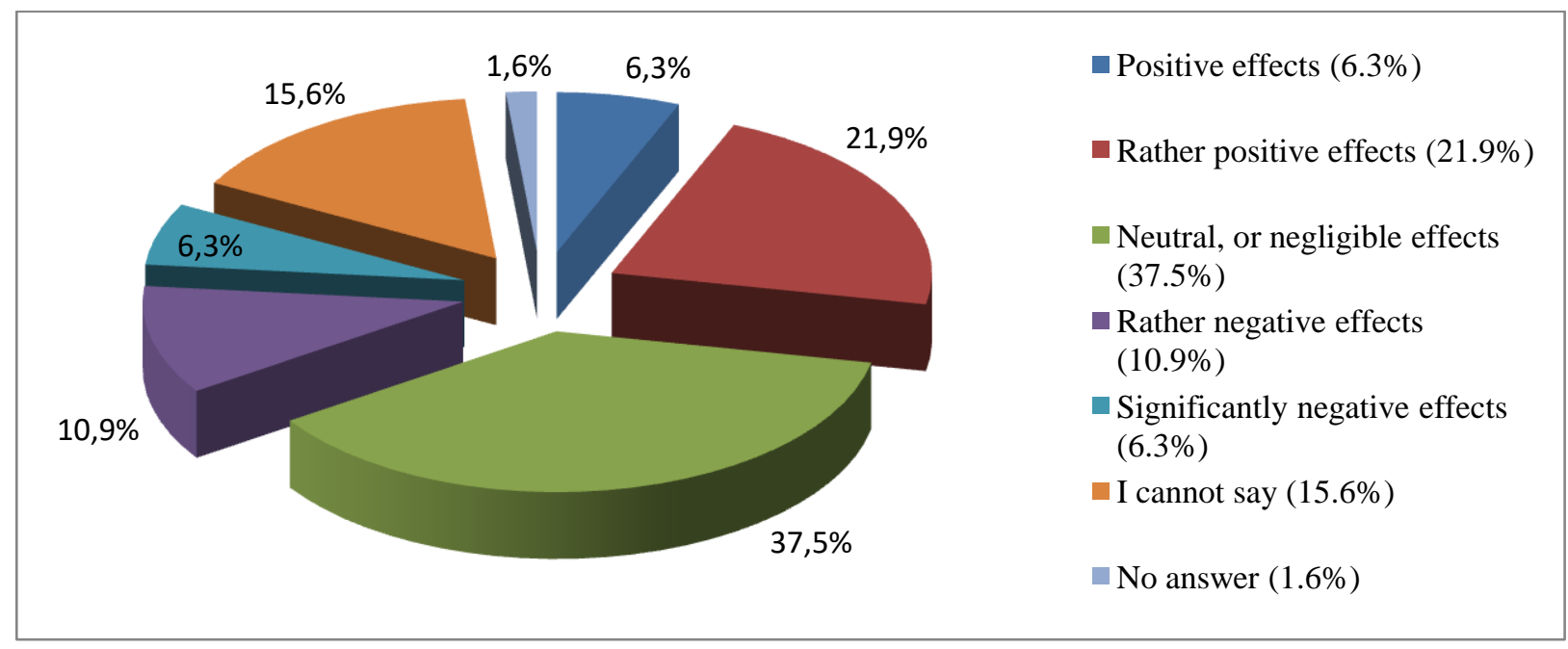

Chart no. 2: The assessment of the code of ethics by the respondents $(N=63)$

Within the given sample of respondents, most of them $(37.5 \%$, or 24 respondents) stated that the code of ethics as an tools for the management of ethics would have neutral, or negligible effects. The positive effects are expected by $28.2 \%, 18$ respondents, with $6.3 \%$ (4 respondents) expecting significantly positive and $21.9 \%$ (14 respondents) rather positive effects of the code of ethics. Negative effects were stated by $17.2 \%$, or 11 respondents, 
namely $10.9 \%$ (7 respondents) expect negative effects and $6.3 \%$ (4 respondents) expect significantly negative effects of the code of ethics. $15.6 \%$, or 10 respondents said that the effects of implementing the code of ethics cannot be assessed and one respondent $(1.6 \%)$ did not comment on the question in the questionnaire. An overview of the quantitative results on this issue is included in chart no. 2.

\section{Discussion}

As a strong aspect of our research we consider the fact that the discussed subject was viewed as a "live" and valid topic by respondents in view of the ongoing process of implementing the code of ethics at the selected faculty. The internal validity of the research is also enhanced by a combination of qualitative and quantitative research timed during the phase of implementation (focus groups) and the period just after the implementation of the code of ethics into practice (questionnaire survey).

Although it would be advisable to repeat the research at other faculties of public higher education institutions, we do not need to think only about the specific faculty when interpreting the results, because several of our respondents have practical experience from other faculties of Slovak and foreign universities. Their views and examples often go beyond the context of one faculty, or one university.

The results of the qualitative research have shown that the views of teachers and internal $\mathrm{PhD}$ students on the implementation of tools and techniques for the management of ethics point to a number of specific risks related in particular to the nature of the code of ethics and its implementation in the environment of the selected faculty. In the context of deficiencies (in terms of content and implementation aspects) that Platková Olejárová states in the analysis of the ethics codes of universities in Slovakia, particular attention needs to be paid to these risks (Platková Olejárová, 2012b, pp. 233-247). From the point of view of the nature of the code of ethics, the outputs from the focus groups point to the need for balance of the aspirational, motivational, as well as the regulatory aspect of the code. As an important moment, which implicitly accentuated the numerous reactions of the speakers, in this context the need to distinguish between the way of regulation through the code of ethics can be considered and the regulation of behaviour through the internal regulations of the faculty valid legislative norms. Several statements in the focus groups also pointed to the need to sensibly set the language of the code, the degree of its universality, specific provisions, in view of the ability of the code of ethics to capture relevant ethical issues. In terms of the quantitative research, $40.6 \%$ of respondents answered the question of what they considered to be important in implementing the code of ethics, saying that the main goal should be to align its wording with legislation and the internal rules of the institution.

The comments of discussants on the process of implementing the code of ethics most often pointed to the communication aspect of the process - the code of ethics should have a consensual character, so it is important to involve as many experts from the faculty as possible while drafting provisions of the code. The attempts to accept the code of ethics for employees and students in this regard require the involvement of bottom-up communication so that it does not imply that the code of ethics is a product of "top-down" processes or that it has been created only by a narrow group of stakeholders. The importance of bottom-up processes in the implementation of functional (in terms of employee-driven) tools of the management of ethics is emphasized in a study conducted by Hill and Rapp (2014). The importance of active communication and involvement of the academic community in the 
implementation of the code of ethics in the academic environment is also pointed out by Králiková $(2009$, pp. 11, 13, 28). Remišová and Lašáková in this context recall that the rate of success of the implementation, and consequently the degree of functionality of the code of ethics is directly dependent on the extent to which the staff of the faculty, or university is involved in the implementation process (Remišová \& Lašáková, 2012, pp. 65-66). The results of the quantitative research at the chosen faculty confirm this view in the sense that while $51.6 \%$ of respondents believe that the code of ethics should be the consensus of the entire academic community, not only its representatives, the opposite alternative (the code of ethics should be the result of the consensus of the "representatives" of the academic community) was identified by $14.1 \%$ of the respondents.

Several statements recorded during the qualitative research phase at the faculty reminded that the code of ethics should be developed and further revised on the basis of an ethical audit that identifies current ethical issues. The need to audit the perception of ethical and moral problems is also accentuated by Olejárová (2008, p. 125). Analysis of the organizational culture, analysis of the ethical environment and the identification of the individual stakeholders between the key stages of the implementation process (before and after the introduction of the code of ethics) are also provided by Remišová and Lašáková (2012, pp. 63-65, 68-69). In this respect, it is important to note that ethical audits can serve as an important mediating tool in the process of the implementation of individual components of ethical infrastructure. In addition to monitoring the ethical environment and identifying problematic areas, it can reach an important moment of communication in the form of the broad involvement of academic staff in the implementation process.

A significant part of the participants in the focus groups drew attention to the risks of the actual implementation of the code of ethics, highlighting in particular the limitation of academic freedom as well as the problem of non-compliance with employee requirements and codified ethical standards (e.g. quantitative scientometric criteria vs. quality of published texts, plagiarism). The tension between the quantitative demands for the work of university educators and the ethics of scientific work is similarly mentioned by Králiková and Kvašňáková (Králiková, 2009, p. 10; Kvašňáková, 2012, pp. 169-179). It is also important to note that the code of ethics or any other tool must not have an effect all across the spectrum, thus eliminating not only the unwanted behaviour of a certain percentage of people, but at the same time significantly impact on work and high-performance of motivated individuals. In this context, Remišová and Lašáková consider the suspicious and reluctant reactions of university educators in the initial stages of the implementation as natural, resulting from the specific character of work in the academic environment and from the autonomy associated with this work (Remišová \& Lašáková, 2012, p. 67). From the point of view of the success of the implementation of ethical infrastructure, these moments place particular demands on the fairness of setting up its individual tools as well as the communication aspects of the whole process. As Platková Olejárová states, a correctly implemented code of ethics should not limit the rights of academic teachers (and academic freedom), but rather confirm and accentuate them (Platková Olejárová, 2012b, pp. 228, 242-243).

Numerous debates in the focus groups emphasized the need to create a "moral climate" through the personal example of faculty management, through a motivating moral model that would significantly enhance the general acceptance of group values. Manroop, Singh and Ezzedeen point to the fact that the human resources system in organizations directly affects their performance as it is closely linked to the moral climate that is part of the organization's 
history and culture (Manroop, Singh \& Ezzedeen, 2014). Avshalom and Rachman-Moore in this regard state that the results of their research, carried out on a sample of 812 employees of a multinational company, point to the fact that in achieving positive results in the area of personal ethical commitment and employees' commitment to organizational values, informal methods (such as the example of personal management of group values) tend to be more effective than formal tools of implementing ethical standards (Avshalom \& Rachman-Moore, 2004, pp. 225-244). From the point of view of the success of the implementation of codes of ethics, the need to involve the whole faculty or university management is accentuated by Remišová and Lašáková (2012, pp. 68, 70-71). The importance of the requirement that the relationship of the faculty management, staff, and students with the code of ethics should not be asymmetrical, also underlines the fact that the majority of respondents $(59.4 \%)$ stated that it is important to ensure compliance with the code of ethics by all stakeholders - employees, faculty leaders, and students.

The assessment of the expected effects of the code of ethics, which was only introduced shortly prior to the quantitative research at the chosen faculty, does not appear to be absolutely negative. Significantly positive, or rather positive effects are expected by $28.2 \%$ of the respondents, while expected negative effects, or rather negative effects are expected by $17.2 \%$ of the respondents. However, it is worth pointing out that $37.5 \%$ of respondents expect neutral, or negligible effects of the established code of ethics. This, in our opinion, underlines the importance of ethical audits, which should continually correct the code of ethics as a tool for the management of ethics with regard to its functionality.

Limitations of this study rest primarly in the limited size of the research sample and the limited comparability of obtained quantitative data due to the specific formulations of the questions that resulted from the statements of our focus groups participants. Improving the understanding of the wider institutional context would be possible by using the established scales, and more accurately understanding of the relationships in specific groups would involve checking the known effects of the implementation of the tools and techniques of the management of ethics. The question of how the control mechanisms and the code of ethics will actually work on the faculty requires also a deeper analysis that goes beyond the scope of this study.

\section{References}

ARMSTRONG, M. (2007): Ǩízení lidských zdrojů: nejnovější trendy a postupy [Human Resources Management: The Latest Trends and Practices]. Prague: Grada.

AVSHALOM, M. A. \& RACHMAN-MOORE, D. (2004): The Methods Used to Implement an Ethical Code of Conduct and Employee Attitudes. In: Journal of Business Ethics, 54(3), pp. 225-244.

BLAŽEK, L. (2011): Management: organizování, rozhodování, ovlivňování [Management: Organizing, Decision-making, Influencing]. Prague: Grada.

BRUHN, J. H., ZAJAC, G., AL-KAZEMI, A. A. \& PRESCOTT, L. D. (2002): Moral Positions and Academic Conduct: Parameters of Tolerance for Ethics Failure. In: The Journal of Higher Education, 73(4) pp. 461-493.

CEJTHAMR, V. \& DĚDINA, J. (2010): Management a organizační chování [Management and Organizational Behaviour]. Prague: Grada. 
CIPRO, M. (2009): Delegování jako způsob manažerského myšlení [Delegation as a Way of Managerial Thinking]. Prague: Grada.

CHOVANCOVÁ, J. \& HUTTMANOVÁ, E. (2014): Social Responsibility in Context of Business Performance and Competitiveness. In: Management 2014: Business, Management and Social Sciences Research. Prešov: Bookman, pp. 135-138.

DEAN, P. J. (1992): Making Codes of Ethics 'Real'. In: Journal of Business Ethics, 11(4), pp. 285-290.

GAO, T., SIEGEL, P., JOHAR, J. S. \& SIRGY, M. J. (2008): A Survey of Management Educators' Perception of Unethical Faculty Behavior. In: Jounal of Academic Ethics, 6(2), pp. 129-152.

GAREGNANI, G. M., MERLOTTI, E. P. \& RUSSO, A. (2015): Scoring Firms' Codes of Ethics: An Explorative Study of Quality Drivers. In: Journal of Business Ethics, 126(4), pp. 541-557.

GLUCHMAN, V. et al. (2012): Profesijná etika - analýza stavu profesijnej etiky na Slovensku [Professional Ethics - Analysis of the State of Professional Ethics in Slovakia]. Prešov: FF PU.

GRISERI, P. (1998): Managing Values. Ethical Change in Organisations. London: MacMillan.

HENDL, J. (2005): Kvalitativní výzkum [Qualitative Research]. Prague: Portál.

HIGGS-KLEYN, N. \& KAPELIANIS, D. (1999): The Role of Professional Codes in Regulating Ethical Conduct. In: Journal of Business Ethics, 19(4), pp. 363-374.

HILL, R. P. \& RAPP, J. M. (2014): Codes of Ethical Conduct: A Bottom-Up Approach. In: Journal of Business Ethics, 123(4), pp. 621-630.

JANKALOVÁ, M., JANKAL, R., BLAŠKOVÁ, M. \& BLAŠKO, R. (2014): Academic Ethics in Conditions of the University of Zilina. In: 2nd International Scientific Conference "Contemporary Issues in Business, Management and Education 2013", Vilnius, November 14, 2013. Procedia - Social and Behavioral Sciences, 110, pp. 568-576.

KAPTEIN, M. (2004): Business Codes of Multinational Firms: What Do They Say? In: Journal of Business Ethics, 50(1), pp. 13-31.

KAPTEIN, M. (2009): Ethics Programs and Ethical Culture: A Next Step in Unraveling Their Multi-Faceted Relationship. In: Journal of Business Ethics, 89(2), pp. 261-281.

KOOCHER, G. P. (2014): Research Ethics and Private Harms. In: Journal of Interpersonal Violence, 29(18), pp. 3267-3376.

KRÁLIKOVÁ, R. (2009): Zavádzanie pravidiel akademickej etiky na slovenských vysokých školách [Implementation of Academic Ethics Rules at Slovak Universities]. Bratislava: TIS SGI, [online]. [Retrieved March 15 2018]. Available at: www.governance.sk/assets/files /publikacie/akademicka_etika.pdf

KVAŠŇÁKOVÁ, L. (2012): Kvalita vedeckej praxe - skúsenosti vysokoškolských učitel'ov/liek a doktorandov/iek Filozofickej fakulty Prešovskej univerzity v Prešove [Quality of Scientific Practice - Experiences of University Teachers and PhD Students of the Faculty of Arts, University of Prešov]. In: V. Gluchman (ed.): Profesijná etika - minulost' a pritomnost' [Professional Ethics - Past and Present]. Prešov: FF PU, pp. 169-179.

LAČNÝ, M. (2008): Postmoderné trendy v podnikovej kultúre. [Postmodern Trends in Corporate Culture]. In: Š. Hittmár et al.: Aktuálne manažérske a marketingové trendy v teórii a praxi [Current Management and Marketing Trends in Theory and Practice]. Žilina: EDIS, pp. 80-83. 
LAČNÝ, M. (2012): Spoločenská zodpovednost' podnikov a korporatívne občianstvo - otázky a výzvy [Corporate Social Responsibility and Corporate Citizenship - Questions and Challenges]. Prešov: Vydavatel'stvo Prešovskej univerzity.

LAŠÁKOVÁ, A. (2005): Organizačná kultúra [Organizational Culture]. In: Acta Culturologica No. 13. Bratislava: FiF UK, pp. 162-173.

LAŠÁKOVÁ, A. (2006): Výskum ideálnych a reálnych hodnôt v rámci organizačnej kultúry [Research of Ideal and Real Values Within an Organizational Culture]. In: Podnikatel'ské prostredie a etika podnikania [Business Environment and Business Ethics]. Bratislava: Ekonóm, pp. 244-247.

MANROOP, L., SINGH, P. \& EZZEDEEN, S. (2014): Human Resource Systems and Ethical Climates: A Resource-Based Perspective. In: Human Resource Management, 53(5), pp. 795-816.

MESSIKOMER, C. M. (2010): Constructing a Code of Ethics: An Experiential Case of a National Professional Organization. In: Journal of Business Ethics, 95(1), pp. 55-71.

MILLER, L. (2008): From Difficult to Disturbed: Understanding and Managing Dysfunctional Employees. New York: AMACOM.

MIOVSKÝ, M. (2006): Kvalitativní přistup a metody v psychologickém výzkumu [Qualitative Approach and Methods in Psychological Research]. Prague: Grada.

MURTEZAN, I., MERXHIVAN, I. \& MENTOR, H. (2010): Multicultural Education and Administration and General Ethic Standards. In: 2nd World Conference on Educational Sciences (WCES 2010), Istanbul, February 4-8, 2010. Procedia - Social and Behavioral Sciences, 2(2), pp. 5875-5875.

OLEJÁROVÁ, G. (2008): Etický kódex zamestnancov vysokých škôl (jeho význam, funkcia a implementácia) [The Code of Ethics of University Employees (its meaning, function and implementation)]. In: D.Slančová, M. Bočák \& I. Žarnovská (eds.): 3. Študentská vedecká konferencia. Zbornik príspevkov [ $3^{\text {rd }}$ Student Scientific Conference. Proceedings]. Prešov: Prešovská univerzita, pp. 122-127.

PLATKOVÁ OLEJÁROVÁ, G. (2012a): O profesijnej etike vysokoškolských učitel'ov cez optiku princípov a noriem v etickom kódexe [On Professional Ethics of University Teachers through the Optics of Principles and Standards in the Code of Ethics]. In: V. Gluchman (ed.): Profesijná etika - minulost' a pritomnost' [Professional Ethics - Past and Present]. Prešov: FF PU, pp. 151-168.

PLATKOVÁ OLEJÁROVÁ, G. (2012b): (Etická) analýza akademickej etiky ako profesijnej etiky v kontexte slovenského vysokého školstva [(Ethical) Analysis of Academic Ethics as a Professional Ethics in the Context of Slovak Higher Education]. In: V. Gluchman (ed.): Profesijná etika - analýza stavu profesijnej etiky na Slovensku [Professional Ethics - Analysis of the State of Professional Ethics in Slovakia]. Prešov: FF PU, pp. 215-265.

PLICHTOVÁ, J. (2002): Metódy sociálnej psychológie zblizka. Kvalitatívne a kvantitatívne skúmanie sociálnych reprezentácii [Methods of Social Psychology Close Up. Qualitative and Quantitative Exploration of Social Representations]. Bratislava: Médiá.

PUTNOVÁ, A. \& SEKNIČKA, P. (2007): Etické ř́zení ve firmě [Ethical Management in the Company]. Prague: Grada.

REMIŠOVÁ, A. (1998): Etické kódexy [Codes of Ethics]. Bratislava: Ekonóm.

REMIŠOVÁ, A. (2004): Etika a ekonomika [On Ethics and Economy]. Bratislava: Ekonóm.

REMIŠOVÁ, A. (2011): Vademékum podnikatel'skej etiky [Vademecum of Business Ethics]. Bratislava: Sprint dva. 
REMIŠOVÁ, A. \& LAŠÁKOVÁ, A. (2012): On the Risks of Implementation of Codes of Ethics in Academic Environment. In: Societal studies, 4(1), pp. 61-74.

REMIŠOVÁ, A. \& WINKLER, I. (2006): Poznatky z komparácie etických kódexov slovenských a nemeckých firiem [The Findings of the Comparison of Codes of Ethics in Slovak and German Companies]. In: Podnikatel'ské prostredie a etika podnikania [Business Environment and Business Ethics]. Bratislava: Ekonóm, pp. 169-173.

RUSSELL-JONES, N. (2006): Management změny [Change Management]. Prague: Portál.

SCHEIN, E. H. (2010): Organizational Culture and Leadership ( $4^{\text {th }}$ Edition). San Francisco: Jossey-Bass.

SILVERMAN, D. (2005): Ako robit' kvalitatívny výskum. Praktická príručka [How to do Qualitative Research. Practical Guide.]. Bratislava: Ikar.

SLYWOTZKY, A. J. (1996): Value Migration. Boston: Harvard Business School Press.

YILDIZ, L. M., IÇLI, G. E. \& GEGEZ, A. E. (2013): Perceived Academic Code of Ethics: A Research on Turkish Academics. In: The Proceedings of 9th International Strategic Management Conference, Riga, June 27-29, 2013. Procedia - Social and Behavioral Sciences, 99, pp. 282-293.

WIELAND, J. (2005): Normativität und Governance. Marburg: Metropolis Verlag. 